\title{
Conflict and Peace Attitudes of Black Sea Region States
}

\author{
Siyana Lutzkanova \\ Nikola Vaptsarov Naval Academy, Varna, Bulgaria
}

\begin{abstract}
The relationship between the democratic form of government and the tendency of states to use force in solving internal and foreign policy problems is one of the central research issues of modern international relations. This report summarizes the results of conflict research on countries in a democratic transformation process. Results of a study of their application for the Black Sea countries for the period 1990-2015 are presented.
\end{abstract}

Keywords: democratic peace, transformation processes, Black Sea region, democratic development

\section{Introduction}

The development of democratic processes in the Black Sea region is one of the major challenges in the current security environment. The specifics of the transition processes following the collapse of the bipolar model resulted in significant differences in the acceptance and implementation of democratic norms and values, which led to the defragmentation of the transformation processes. Together with the usual shortcomings of less consolidated democratic societies such as market economy deficits, protection of civil rights and freedoms, and high levels of corruption, etc., one of the most serious risks is the level of conflict in countries in a transformation process. The relationship between political order and conflict levels is one of the most analyzed issues in contemporary international relations. The perception that the democratic states "bring peace" helped legitimize a number of US and UK policies towards common democratization of the world.

However, what is the willingness to use force to resolve external and domestic problems in countries that are in a transformation process? This is a little studied aspect within the framework of the "democratic peace" theories. The events over the last five years in the Black Sea region have shown a tendency to confirm previous studies for a higher level of conflict in the transforming countries. One important point: This conclusion concerns newly created countries in which a new political order is introduced quickly and ad hoc. Such Black Sea countries are Georgia and Ukraine. In the rest, there is a relatively smoother and more adaptable transition to full membership in European and Euro-Atlantic structures.

This report is a review of an in-depth study of democratic transformation processes in the Black Sea countries in the context of the "democratic peace" theory. Due to the dynamics of the evolving events, the conclusions are not final but sufficiently relevant to outline the trends and prospects for the levels of conflict in the studied countries. Due to its limited scope, the report aims to outline the context and the theoretical framework of the study and does not empirically analyze the impact of all factors on the behavior of the analyzed countries.

Siyana Lutzkanova, Ph.D., Chief Assistant Professor, Nikola Vaptsarov Naval Academy. 


\section{The "Democratic Peace" Theory}

The liberal theory of "democratic peace" favors the idea that the republican form of government calls for a "peaceful order" in international relations. This statement finds its predecessors far back in the age of enlightenment and the time of philosophers like Rousseau, Abbat Saint Pierre, and others. In their writings they describe the relationship between peace and the form of government. The father of the theory of "democratic peace” is the German philosopher Immanuel Kant (2003) with his work For the eternal peace.

The debate in political science on the relationship between the form of government and foreign policy has begun in the 1980s of the 20th century. Then Michael Doyle paid special attention to the fact that there is a very weak tendency in the exercise of military power in the relations between the democratic countries (Doyle, 1983). Since then, international relations has been deeply concerned with this issue of political science, especially in the last decade, which has increasingly favored the idea of "universal democratization" of the world, which would lead to a state of peace.

However, the methodology used by the theory of "democratic peace" contains a number of contradictions. The research complex mainly uses qualitative analysis and considers democracy as an independent variable and peace, respectively war, as a dependent variable. These three categories are so difficult to operate that contradictions are inevitable (Geis, 2001, p. 283). It should be noted that the reason for the contradictory statistical results of the supporters of liberal theory of "democratic peace" is not a mistake in the statistical method but in the general lack of a unified definition of the terms "democracy" and "war". One of the greatest critics of the theory, Christopher Lane, even claims that the desired results have been achieved by adapting the definitions and categories to the thesis that democracies do not fight each other (Layne, 1994, pp. 5-49, p. 490; Spiro, 1994, pp. 50-86, p. 55).

The definition of "war" used in the research of "democratic peace" is quite controversial related to the modern security environment. "War" is considered an inter-state manifestation of violence, as a result of which the armed forces of the involved countries count more than 1,000 victims (Russett, 1993, p. 16). This definition does not include colonial wars, military disputes, humanitarian interventions, and others. The imperialist wars of the European countries during the 19th to the mid-20th centuries are an example of the frequent participation of democratic countries in armed conflicts initiated by them and not as a result of self-defense. Another example is given by Sebastian Rosato (2003) with US interventions during the Cold War (pp. 585-602). There is no absolute proof that the attacked countries Guatemala, Chile, or Brazil had real intent to join the communist bloc. The left-oriented governments of these countries are democratically elected, and at that time have not enjoyed the necessary confidence of Washington. Not only this, but also by the exercise of military power, the US irreversibly destabilized these governments, and they were replaced by autocratic (but anti-communist) regimes. Rosato argued that these attacks were driven only by economic and ideological interests. These interventions stayed out of public eyes in order to avoid negative reactions. It can be assumed that at that time, the United States did not perceive these young democracies as such and therefore treated them hostilely.

There is another critical argument in the literature concerning the statistical evaluation. It concerns Correlates of War-Project, which results are widely used. Risse-Kappen (1994) finds that the calculations very often include "absurd" pairs of countries that are neither geographically nor resource able to carry out any kind of military action among themselves (p. 369). One such pair is Iceland-Luxembourg. This, however, has an 
impact on the final results in favor of "non-in-war-involved democracies". If these meaningless pairs of countries are excluded from the calculations, the end result would not be so convincing. There are attempts in the literature to find a solution to these contradictions, two of which are considered to be accepted by the critics. The first one is the research of Bruno de Mesquita, James Morrow, Randolph Siverson, and Alastair Smith (1999, pp. 791-807). The authors proceed from the fact that elected governments decide to apply military force abroad if they are forced, or if success is quick and guaranteed (De Mesquita et al., 1999, p. 791). For the asymmetric conflicts applies the opposite: When democratic countries are not convinced in their victory, they do not act riskily because a loss guaranteed will deprive them of power (De Mesquita et al., 1999, p. 801). Here, however, it should be noted that this kind of "peace" between democratic states does not always coincide with their behavior. For example, weaker Iceland shows an incredible strong position towards UK in a number of disputes related to the expansion of the island's marine environment and the right to fish there.

The second attempt to resolve contradictions in theory is made by the famous German political scientist Ernst Otto Czempiel. He accepts the normative argument that, as a whole, democratic parties exercise force only when it is inevitable. Civil society rejects anything that would hurt it, and governments respect its will. Every deviation from this idealism is explained by the fact that no democracy has yet reached the ultimate form of democratic governance and they are all actually in the process of transformation (Czempiel, 1996, p. 82). The fact that in these countries particular interests still influence the state monopoly supports this argumentation. Also, in many democratic countries, the interest of civil society in foreign policy issues is too low. If we consider on a case-by-case basis to what extent foreign policy decisions are made with the consent of civil society, the results may show low numbers. By removing these countries from the list, the statistical result will change.

\section{The Transformation Processes in the Black Sea Region in the Context of the "Democratic Peace" Theory}

What are the attitudes of countries in transition to use power is little explored within the framework of the "democratic peace" theory. The contradictions in the behavior of such states are quite problematic. Described are the results and conclusions from statistical surveys on the relationship between transformation processes and levels of conflict and their validity for the Black Sea states from 1990 to 2015.

It is important to note the differences in accepted definitions of terms "democracy" and "democratic transition". The different criteria of definition lead to different results. That is why before the statistics give us an answer to the questions, it is necessary to analyze precisely the problem that the researchers of the processes of systemic transformation deals with, namely: When a system is "democratic" and from what point forward it is considered "institutionalized and consolidated democracy" (Merkel, 1995, p. 53)?

Since the regimes fall in Eastern Europe, for example, different approaches and policies of democratization have led to different forms of such or even new forms of authoritarian leadership. These countries in a transition process form a subcategory of the democratic regime, the so called "defective democracies” (Merkel \& Croissant, 2000, pp. 3-30). Defective democracy is a kind of the rule of law related to the absence, limitation, or non-observance of one or more criteria that characterize it (eg. constitutional violations, inadequate respect for citizens' freedoms, unbalanced division of powers with concentration of power in one institution, violations of electoral law, violation of free access to information, etc.). For Black Sea countries, according to the three most common indicators for measuring democracy, Russia and Ukraine belong 
to this group (see Figure 1). Georgia and Turkey are considered transitional democracies beyond the defective and at least the level of consolidated ones according to a number of indicators.

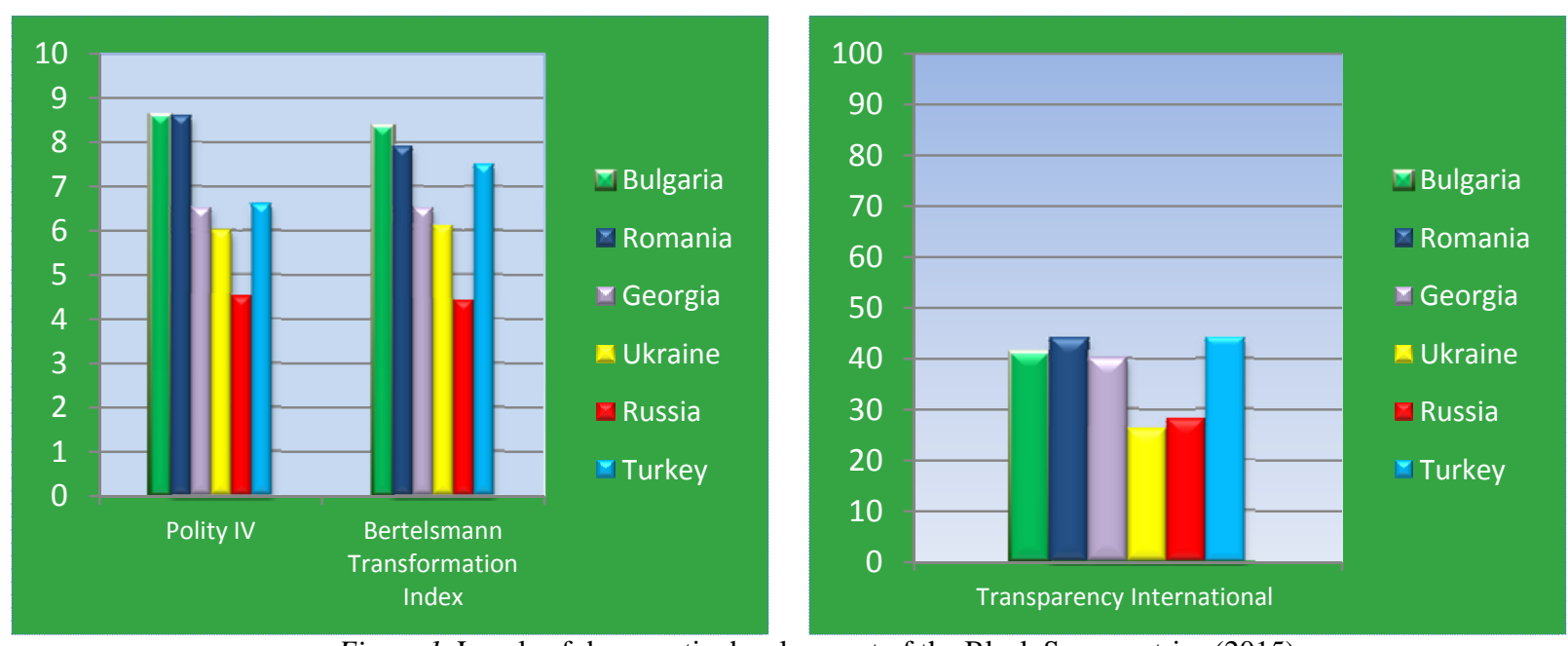

Figure 1. Levels of democratic development of the Black Sea countries (2015).

Sources: http://www.systemicpeace.org/polity/polity4.htm, http://www.bti-project.de/bti-home/,

http://www.transparency.org/country

What are the reasons for the low level of conflict of the other countries-Bulgaria and Romania? Economic and institutional reasons stem from the positive influence of existing market ties, on one hand, and the positive influence of the membership of countries in international organizations, regimes, and alliances, on the other hand.

Institutional interpretations have long existed and, in their view, participation in international institutions guarantees dialogue and creates a framework for peaceful conflict resolution. The argument that alliances are a guarantee of peace has been repeatedly analyzed. Russett/Oneil concluded: "The greater the number of international organizations in which the pairs of countries are members, the more the forums for peaceful resolution of conflicts and the greater the prospect of peace” (Russett \& Oneal, 2001, p.170) ${ }^{1}$. The question remains whether democracies are members of different regimes simply because they are democratic or are led by other interests (economic, security, etc.).

By broad trade relations and partnership in the economic sphere, cooperation is also stimulated in other areas. Since the parties are economically bound, a possible military conflict between them would lead to significant losses for all actors and would affect their economies in significant proportions (Russett \& Oneal, 2001, pp. 125-156). So, economic dependence plays a significant peace trigger.

Edward Mansfield and Jack Snider offer analysis of the relationship between system transformation and tendency to non-peaceful conflict resolution. In the context of the methodology they use, the results are predictable: The likelihood that transition countries initiate or engage in armed conflict is significantly greater than stable democratic or purely autocratic countries. It is also greater for countries that have made a rapid change from autocratic to democratic rules without going through an autocratic phase (eg, Russia) (Mansfield \& Snyder, 1995, p. 6). One reason for this result is that the authors point to the rivalry between the new and the

\footnotetext{
${ }^{1}$ However, the authors do not specify whether this conclusion applies to international institutions with a homogeneous composition (consisting only of democratic countries) or heterogeneous (consisting of countries with different forms of government). We find this criticism in Andreas Hasenclever (2002, p. 83).
} 
old elites, each of them trying to apply and legitimize its power. Through media manipulations, increased nationalist propaganda or aggressive attitude to the new order, the rival elites organized strong lobbying for influencing the public opinion of fragile civil society and weak state institutions.

Several studies criticize Mansfield/Snider's definitions and statistical methods. With different categorisation of dependent and independent variables and calculation method, different contradictory results arise, rejecting Mansfield/Snider's thesis that systemic transformation does not reduce the tendency of these states to use military force (Ward \& Gleditsch, 1998, p. 58).

Thompson/Tucker's research does not link the processes of systemic transformation to military attitude. Statistically, there is no link between both democratic and autocratic transition processes and the tendency to use military force (Thompson \& Tucker, 1997, pp.449-450).

The common among these studies is the generalization and unification. There is no analysis of the individual transformation processes in the countries and this leads to differences in statistical results. Typical examples are the established high levels of military power use of Serbia, Croatia, and Azerbaijan, which, before 1991, were not autonomous countries, and in which processes are first and foremost related to the formation of their nationality and statehood. It is very difficult to distinguish these processes from those of the democratic transition (Ward \& Gleditsch, 1998, p. 60). External factors can also influence higher tendencies, and they are usually not related to the ongoing transition process. This tendency is logical if the country concerned is surrounded by autocratic ones or if it maintains political or economic contacts with such countries (Ray, 1997, pp.60-62).

\section{Conclusion}

In conclusion, the results of the Mansfield/Snyder's study show the relevancy of the theory of "democratic peace" in stable democratic countries. There are three conclusions that find statistical confirmation for the Black Sea countries.

The first conclusion states that, in principle, transition countries are involved on average $60 \%$ more in armed conflicts than others. So, the processes of democratization increase the likelihood of intra- and foreign-policy conflicts occurring in young democracies based on five- and ten-year periods. The lack of a consolidated democratic system is associated with a higher tendency to conflict in a foreign policy context. This conclusion is supported by the analysis of the level of conflict in part of the Black Sea countries over the last five years.

The second conclusion shows a high tendency for the use of force in newly created countries, whose transition process began ad hoc. Such countries in the Black Sea region are Georgia and Ukraine.

The third conclusion definitely shows differences in the relationship between the system transition and the tendency to conflict between countries of the so-called Great Powers Group, such as Russia. This distinction is important because here the authors draw attention to the need for research into the theory of transformation processes considering these differences in the results (Mansfield \& Snyder, 1995, p. 20). Since these countries play a very important role on the international scene, such studies are extremely useful for analyzing their behavior and the specifics of their transformation process. The question arises whether a great power country in a transition process has a different behavior in international security, from other smaller countries. 


\section{References}

Czempiel, E. O. (1996). Kants Theorem. Oder: Warum sind die demokratien (noch immer) nicht friedlich? Zeitschrift fuer Internationale Beziehungen, 3(1), 79-101.

De Mesquita, B., Morrow, J., Siverson, R., \& Smith, A. (1999). An institutional explanation of the democratic peace. American Political Science Review, 93(4), 791-807.

Doyle, M. (1983). Kant, legal legacies, and foreign affairs: Part 1. Philosophy and Public Affairs, 12(1), 205-335.

Enterline, A. (1996). Correspondence: Democratization and the danger of war. International Security, 20(4), 176-207.

Geis, A. (2001). Diagnose: Doppelbefund-Ursache: ungeklaert? Die Kontroversen um den demokratischen Frieden. Politische Vierteljahreszeitschrift, 42(2), 282-298.

Hasenclever, A. (2002). The democratic peace meets international institutions-Ueberlegungen zur internationalen Organisation des demokratischen friedens. Zeitschrift fuer internationale Beziehungen, 9(1), 5-111.

Kant, I. (2003). Zum ewigen Frieden, Ein philosophischer Entwurf. Stuttgart: Reclam.

Layne, C. (1996). Kant or Cant: The myth of the democratic peace. International Security, 19(2), 5-49.

Mansfield, E., \& Snyder, J. (1995). Democratization and the danger of war. International Security, 20(1), 5-38.

Merkel, W., \& Croissant, A. (2000). Formale und informale institutionen in defekten demokratien. Politische Vierteljahresschrift, 41, 3-30.

Merkel, W. (1995). Theorien der transformation: Die demokratische Konsolidierung postautoritaerer Gesellschaften. Politische Theorien in der Aera der Transformation (Politische Vierteljahresschrift Sonderheft 26), 30-58.

Ray, J. L. (1997). The democratic path to peace. Journal of Democracy, 8(2), 49-64.

Risse-Kappen, T. (1994). Wie weiter mit dem demokratischen Frieden? Zeitschrift fuer Internationale Beziehungen, 1(2), 367-379.

Rosato, S. (2003). The flawed logic of democratic peace theory. American Political Science Review, 97(4), 585-602.

Russett, B., \& Oneal, J. (2001). Triangulating peace: Democracy, interdependence, and international organizations. New York 2001.

Russett, B. (1993). Grasping the democratic peace: Principles for a post-Cold War world. Publisher: Princeton University Press.

Schmidt, M. (2000). Uebergaenge vom autoritaeren Staat zur Demokratie. In M. G. Schmidt (Ed.), Demokratietheorien: Eine einführung (pp. 460-487). Publisher: VS Verlag für Sozialwissenschaften.

Spiro, D. (1994). The insignificance of the liberal peace. International Security, 19(2), 50-86.

Thompson, W., \& Tucker, R. (1997). A tale of two democratic peace critiques. Journal of Conflict Resolution, 41(3), 428-454.

Ward, M., \& Gleditsch, K. (1998). Democratizing for peace. American Political Science Review, 92(1), 51-62. 